\title{
Early parenteral feeding of amino acids
}

\author{
J SAINI, P MACMAHON, J B MORGAN,* AND I Z KOVAR \\ Department of Child Health, Charing Cross and Westminster Medical School, London, and *Department of \\ Biochemistry, University of Surrey, Guildford
}

SUMMARY Serial 24 hour balance studies of nitrogen and energy were carried out over 10 days in two groups of ventilator dependent preterm infants, of comparable weight and gestational age. In one group $(n=10)$ a parenteral amino acid source (Vamin 9) was started within 24 hours of birth, and in the other group $(n=11)$ it was not started until 72 hours. The feeding protocol was otherwise identical. The nitrogen intake (286 compared with $21 \mathrm{mg} / \mathrm{kg} / \mathrm{day})$, energy intake (188 compared with $151 \mathrm{~kJ})$, and nitrogen retention (120 compared with $-133 \mathrm{mg} / \mathrm{kg} / \mathrm{day})$, were all significantly higher during the first three days of life in the group in which the amino acid solution was started early. There were no differences by 7-10 days. The early introduction of amino acids improves the early nutritional state of sick preterm infants.

Infants of less than 30 weeks' gestation are born at a time of otherwise rapid intrauterine brain and body growth. Unfed, these babies have limited energy reserves ${ }^{1}$ and the rapid establishment of postnatal nutrition is essential if they are to survive intact. ${ }^{2} \mathrm{~A}$ fetus of comparable postconceptional age is a good nutritional model for the preterm infant. ${ }^{3}$ Using this model, nitrogen retention of about $320 \mathrm{mg} / \mathrm{kg} /$ day would be needed for the preterm infant of 24-34 weeks' postconceptional age (E Widdowson, personal communication). ${ }^{4}$ Parenteral feeding with a nitrogen solution from birth would thus seem appropriate if this target is to be achieved and if early negative nitrogen balance is to be avoided.

Because of concerns about fibrin and casein hydrolysate protein solutions, many neonatal units continue to delay the introduction of an amino acid solution for several days after birth, as older solutions were associated with various metabolic complications including hyperammonaemia ${ }^{5}$ and acidosis. ${ }^{6}$ The more recent crystalline amino acid solutions have been modified to reduce these risks.

Preterm infants, particularly if they are unwell, are likely to require nutrients and energy in the immediate transitional period after birth at rates at least similar to those available in the uterus. We aimed to find out if there was any increase in overall nitrogen retention and energy intake in sick infants of low birthweight who were ventilator dependent and who were given amino acids intravenously from birth.

\section{Patients and methods}

Ventilator dependent preterm infants of less than 30 weeks' gestation were entered sequentially on admission to the neonatal intensive care unit into? one of two intravenous feeding regimen groups. Those in group E (early) were given intravenous glucose and nitrogen (as Vamin 9, KabiVitrum), within 24 hours of birth, while group L (late) initially received intravenous glucose alone, and nitrogen only after 72 hours of life. The nitrogen delivery rate in both groups was increased progressively over three days from $1 \mathrm{~g} / \mathrm{kg} /$ day to a maximum of $3 \mathrm{~g} / \mathrm{kg} / \mathrm{day}$. Intravenous fat (Intralipid, KabiVitrum) was introduced to both regimens at 7 days postnatal age. The infants continued to receive intravenous nutrition (based on standard clinical criteria) until oral feeding could safely be established. The feeding regimens of the two groups differed only in the time of introduction of amino acids. The vitamin intakes (for example, ascorbic acid) were similar in both groups. A computer based protocol was used for the prescription of parenteral solutions.

The criteria for inclusion in the study were that the infants completed serial 24 hour balance studies of nitrogen and energy over the first 10 days of life, and that at least $75 \%$ of their nitrogen and energy was delivered intravenously. Thirty two infants were initially recruited: 17 in group $E$ and 15 in group $L$. One infant in group $E$ and two in group $L$ died within 72 hours of age; enteral feeding was estab- 
lished in the first few days in two infants in each group, and in four infants (three in group $\mathrm{E}$ and one in group L) urine collections were incomplete. Eleven infants in group $\mathrm{E}$ and 10 in group $\mathrm{L}$ therefore met all the study criteria for analysis.

Six of the 11 infants in group $E$ had periods (up to 48 hours) when they could not receive protein solution-two on days 4 and 5 because of precipitation of the solution as a result of over prescription of calcium and phosphate; one on day 2 , a second on day 3 , and a third on day 5 because of pronounced hyperglycaemia and presumed infection; and the sixth infant for 48 hours on day 4 because of conjugated hyperbilirubinaemia. Two infants in group L did not receive protein for 24 hour periods-one on day 5 and one on day 6-because of precipitation of the solution.

All infants required intensive medical and nursing care support as defined by the British Paediatric Association criteria. ${ }^{7}$ All infants were initially dependent on ventilators. Four of 11 in group $E$ and two of 10 in group L developed pneumothoraces, one infant in each group developed post haemorrhagic hydrocephalus, two in each group developed metabolic acidosis ( $\mathrm{pH}$ less than 7.20), four of 11 in group E and two of 10 in group L had a clinically important patent ductus arteriosus, and one of 11 and three of 10 , respectively, developed systemic infection.

Serial metabolic balance studies of nitrogen and energy were carried out for 10 days. Timed 24 hour collections of urine and faeces were made; traditional markers could not be used because there was initially no enteral intake. Urine was collected from an attached bag with any leakage collected on preweighed disposable nappies, and faeces were collected into disposable one way nappy liners. Each 24 hour aliquot of urine and faeces was stored at $-20^{\circ} \mathrm{C}$ until analysis. Nitrogen and energy content was analysed by Kjeldahl's technique adapted for small volumes, and ballistic bomb calorimetry, respectively.

Each infant was nursed in a conventional incubator in a thermoneutral environment during the study period. Fluid volume management was according to standard clinical practice. A record was kept of each 24 hours' (from the start of urine collection) parenteral and enteral nitrogen and energy intake.

Random assay checks of nitrogen and energy content of the parenteral solutions and milk feed given in the same 24 hour period were carried out to confirm data supplied by the pharmacy and the milk producer. Nude body weight was recorded daily on an electronic scale accurate to $0.5 \mathrm{~g}$. Crown-heel length using a measuring board accurate to $0.5 \mathrm{~mm}$ and occipitofrontal head circumference were recorded weekly by a single observer (JS).

Blood was taken daily for routine electrolytes and biochemical analysis, and for plasma amino acids profiles on day 5 of the study. Amino acid analysis was by high performance liquid chromatography of orthophthalaldehyde derivatives of amino acids. Protein was removed from plasma with sulphasalicylic acid, adjusted to $\mathrm{pH} 9 \cdot 5$, and the amino acids reacted with orthophthalaldehyde. The resulting derivatives were separated by gradient high performance liquid chromatography on a reversed phase C18 column and detected fluorimetrically. The method has been extensively validated against other methods of analysis and gives reliable results (DA Reaveley, unpublished observations).

Statistical analysis was by the unpaired Student's $t$ test and linear regression analysis, and the study was approved by the hospital ethics committee.

\section{Results}

At the time of entry to the study the two groups differed significantly only in the time of introduction of amino acids $(\mathrm{p}<0.001)$ (table 1$)$. At 10 days, seven infants in group $E$ were still ventilator and oxygen dependent, while 10 in group $\mathrm{L}$ were ventilator dependent and eight oxygen dependent.

The nitrogen and energy content of the parenteral solutions supplied by the pharmacy and any enteral milks used were within $2 \%$ of the amount that we intended.

The mean (SEM) 24 hour nitrogen retention for each infant over the study period is shown in fig 1 . The nitrogen retention differed between the two groups in the first 72 hours of life $(p<0.001)$. All infants in group $\mathrm{E}$ were in positive nitrogen balance throughout the study period with an overall mean (SEM) nitrogen retention of $122(18) \mathrm{mg} / \mathrm{kg} / \mathrm{day}$. All infants in group $L$ were in negative nitrogen balance during the first 72 hours of life with a mean (SEM)

Table 1 Comparability of the two groups. Figures are mean (SEM)

\begin{tabular}{|c|c|c|c|}
\hline & \multicolumn{3}{|c|}{ Parenteral amino acid solution given } \\
\hline & $\underset{(n=11)}{\text { Within }} 24 h$ & $\begin{array}{l}\text { At } 72 h \\
(n=10)\end{array}$ & $\begin{array}{l}p \\
\text { Value }\end{array}$ \\
\hline Male:female & $9: 2$ & $6: 4$ & \\
\hline Gestation (weeks) & $28 \quad(1)$ & $2 \dot{8} \quad(1)$ & NS \\
\hline Birth weight (g) & 1087 (95) & $990(78)$ & NS \\
\hline $\begin{array}{l}\text { Age of introduction of } \\
\text { amino acids (hours) }\end{array}$ & 23 & & $<0.001$ \\
\hline Supine length $(\mathrm{cm})$ & $36 \quad(4)$ & $\begin{array}{ll}10 & (4) \\
36 & (3)\end{array}$ & NS \\
\hline Head circumference $(\mathrm{cm})$ & $26 \quad(2)$ & $25 \quad(2)$ & NS \\
\hline
\end{tabular}




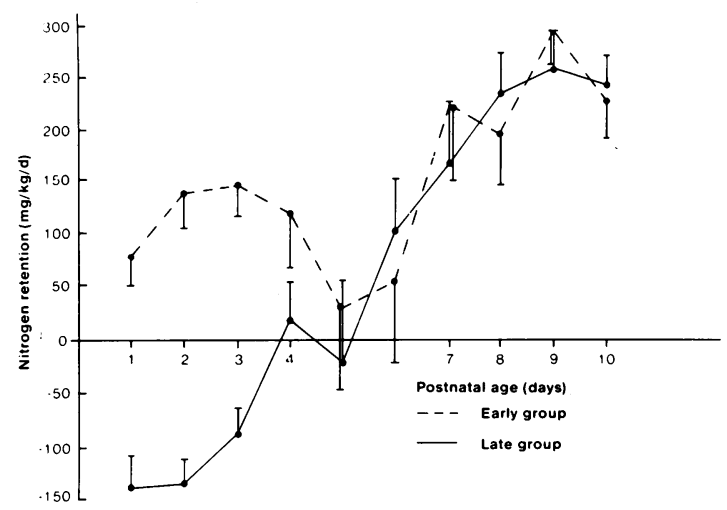

Fig 1 Mean 24 hour nitrogen retention $(\mathrm{mg} / \mathrm{kg} / \mathrm{d})$ for the two groups over the 10 day study period. Bars indicate $S E M$. Significant differences were recorded at days 1,2 , and $3(p<0.001)$. In the 'early group' the amino acid solution was given within 24 hours and in the 'late group' it was given at 72 hours.

negative balance of $-133(23) \mathrm{mg} / \mathrm{kg} / \mathrm{day}$, compared with group $E$ who retained 120 (6) $\mathrm{mg} / \mathrm{kg} / \mathrm{day}$. After day 3 there was no difference in nitrogen retention between the two groups.

The total input and output balances over 10 days of intravenous and enteral intake and urine and faecal output are shown in table 2. There was no difference in fluid intake between the groups. In both groups a lower fluid intake was recorded in the first 24 hours of life compared with the remaining study period. The maximum mean (SEM) fluid intake in both groups was at 7 days postnatal age, being $149(8) \mathrm{ml} / \mathrm{kg} /$ day in group $\mathrm{E}$ and $148(8)$ $\mathrm{ml} / \mathrm{kg} /$ day in group $\mathrm{L}$. The mean percentage enteral energy intake of total energy intake at 10 days of age was $18 \%$ in group $\mathrm{E}$ and $24 \%$ in group $\mathrm{L}$. There was no difference in the maximum mean (SEM) recorded urine outputs (both on day 5) of 111 (10) $\mathrm{ml} / \mathrm{kg} /$ day, and $110(13) \mathrm{ml} / \mathrm{kg} /$ day, in groups $\mathrm{E}$ and

Table 2 Daily intake and output during the 10 day study period. Figures are mean (SEM)

\begin{tabular}{llcc}
\hline & & \multicolumn{2}{c}{ Parenteral amino acid solution given } \\
\cline { 3 - 4 } & & $\begin{array}{l}\text { Within } 24 h \\
(n=10)\end{array}$ & $\begin{array}{l}\text { At } 72 h \\
(n=11)\end{array}$ \\
\hline Total fluid intake & $(\mathrm{m} / \mathrm{kg} / \mathrm{d})$ & $126(8)$ & $126(8)$ \\
Enteral intake & $(\mathrm{m} / \mathrm{kg} / \mathrm{d})$ & $9(3)$ & $11(4)$ \\
Urine output & $(\mathrm{m} / \mathrm{kg} / \mathrm{d})$ & $85(5)$ & $97(3)$ \\
Faecal output & $(\mathrm{g} / \mathrm{kg} / \mathrm{d})$ & $0.5(0 \cdot 1)$ & $0.7(0.3)$ \\
\hline
\end{tabular}

There were no significant differences between the groups.
Table 3 Daily energy and nitrogen intakes given as mean $(S E M)$, and energy:protein ratio (\%) in the two groups

\begin{tabular}{|c|c|c|c|c|}
\hline & \multirow[t]{2}{*}{ Days } & \multicolumn{3}{|c|}{$\begin{array}{l}\text { Parenteral amino acid solution } \\
\text { given }\end{array}$} \\
\hline & & $\begin{array}{l}\text { Within } \\
24 h \\
(n=11)\end{array}$ & $\begin{array}{c}\text { At } 72 h \\
(n=10)\end{array}$ & p Value \\
\hline Energy $(\mathrm{kJ} / \mathrm{kg} / \mathrm{d})$ & $\begin{array}{l}1-3 \\
4-6 \\
7-9\end{array}$ & $\begin{array}{l}188(13) \\
264(13) \\
297(13)\end{array}$ & $\begin{array}{l}151(4) \\
268(13) \\
330(17)\end{array}$ & $\begin{array}{l}0.001 \\
\text { NS } \\
0.05\end{array}$ \\
\hline Nitrogen $(\mathrm{mg} / \mathrm{kg} / \mathrm{d})$ & $\begin{array}{l}1-3 \\
4-6 \\
7-9\end{array}$ & $\begin{array}{l}286(15) \\
286(50) \\
412(34)\end{array}$ & $\begin{aligned} 21 & (6) \\
232 & (19) \\
423 & (24)\end{aligned}$ & $\begin{array}{l}0 \cdot 001 \\
\text { NS } \\
\text { NS }\end{array}$ \\
\hline $\begin{array}{l}\text { Energy:protein ratio } \\
(\%)\end{array}$ & $\begin{array}{l}1-3 \\
4-6 \\
7-9\end{array}$ & $\begin{array}{l}17 \\
12 \\
15\end{array}$ & $\begin{array}{l}1^{*} \\
10 \\
13\end{array}$ & \\
\hline
\end{tabular}

${ }^{*}$ Refers to day 3 only.


Fig 2 Energy intake $(\mathrm{kJ} / \mathrm{kg} / \mathrm{d})$ and nitrogen retention $(\mathrm{mg} / \mathrm{kg} / \mathrm{d})$ for the group in which the amino acid solution was given within 24 hours (above) $(r=0 \cdot 35, p<0.001)$, and for that in which it was given at 72 hours (below) $(r=0.66$, $p<0.001$ ). Each point represents a 24 hour balance period. 
L, respectively. Faecal output was less than $0.7 \mathrm{~g} / \mathrm{kg} /$ day in both groups throughout the study.

The mean daily nitrogen $(\mathrm{mg} / \mathrm{kg} /$ day $)$ and energy $(\mathrm{kJ} / \mathrm{kg} /$ day) intake expressed in 72 hour periods is given in table 3 . Nitrogen and energy intake was greater in group $E$ in the first 72 hours $(p<0.001)$; mean energy intake was greater in group $\mathrm{L}$ at 7-9 days $(p<0.05)$. In group $L$ protein intake contributed less than $2 \%$ of the overall energy intake in the first 72 hours. Otherwise the protein:energy ratio was greater than $10 \%$ in both groups throughout the study (table 3 ).

The association between mean daily nitrogen retention $(\mathrm{mg} / \mathrm{kg} /$ day $)$ and energy intake $(\mathrm{kJ} / \mathrm{kg} /$ day $)$ is shown in fig 2 ; there was. a positive correlation in both groups $(r=0.35, p<0.001$ in group $E$; $r=0.66, p<0.001$ in group $L$ ). There was a wide range of nitrogen retention for individual infants at any given energy intake. Energy intakes of greater than $418 \mathrm{~kJ} / \mathrm{kg} /$ day were achieved in only seven 24 hour balance periods, one in group $\mathrm{E}$, and six in group $L$. The percentage of total nitrogen intake retained on days $1-3,4-6$, and 7-9 postnatal age was 42,18 , and $60 \%$ in group $E$, and 0,22 , and $51 \%$ in group L, respectively.

The increases in length, occipitofrontal head circumference, and total change in body weight were similar in both groups. Overall weight change was not significantly different in either group (table 4). Group E had regained $95 \%$ and group L $93 \%$ of their birth weights by 10 days of age. The age of maximum weight loss was day 6 postnatal age in group E, with $10 \%$ loss from birth weight, and day 7 in group $\mathrm{L}$ with $12 \%$. There was no association between increase in length or head circumference, and energy or nitrogen intake, in either group.

Plasma aminograms at 5 days of age were

Table 4 Changes in weight, occipitofrontal head circumference, and crown-heel length in the two groups. Figures are mean (SEM)

\begin{tabular}{llllll}
\hline & Days & \multicolumn{3}{l}{$\begin{array}{l}\text { Parenteral amino acid } \\
\text { solution given }\end{array}$} \\
\cline { 3 - 6 } & & $\begin{array}{l}\text { Within } \\
24 h\end{array}$ & $\begin{array}{l}\text { At } 72 h \\
(n=10)\end{array}$ \\
& & $(n=11)$ & & \\
\hline Weight change (g/kg/d) & $1-3$ & $-23(10)$ & -23 & $(6)$ \\
& $4-6$ & $-10(16)$ & -8 & $(21)$ \\
$\begin{array}{c}\text { Occipitofrontal head } \\
\text { circumference } \\
\text { (cm/week) }\end{array}$ & $7-9$ & $-3(14)$ & $-17(14)$ \\
$\begin{array}{c}\text { Crown-heel length } \\
\text { (cm/week) }\end{array}$ & $1-10$ & 0.4 & $(0 \cdot 1)$ & 0.4 & $(0 \cdot 1)$ \\
\hline
\end{tabular}

*Excluding one patient from each group with hydrocephalus. available only for nine infants in group $E$ and seven in group L. A high phenylalanine concentration (greater than $300 \mu \mathrm{mol} / \mathrm{l}$ ) was found in two infants in group $\mathrm{E}$ and none in group L. Five infants in group $\mathrm{E}$ and four in group $\mathrm{L}$ had plasma tyrosine concentrations greater than $300 \mu \mathrm{mol} / \mathrm{l}$. Other amino acids were within the laboratory reference range for neonates.

\section{Discussion}

There is no general agreement on the ideal age at which to introduce an intravenous nitrogen solution to the feeding regimen of a preterm infant. In the infant who can be fed enterally, a protein source (milk) is introduced within hours of birth. These babies are usually well and often larger than the babies studied here. We would suggest that there is no reason why the sick infant requiring intravenous feeding should not be offered amino acids from day 1 .

In this study infants in the late introduction group had a significant negative nitrogen balance until intravenous nitrogen was introduced on day 3 . The mean negative balance of $-133 \mathrm{mg} / \mathrm{kg} /$ day is equivalent to a loss of $0.849 \mathrm{~g} / \mathrm{kg} /$ day of body protein, or $2.5 \mathrm{~g}$ protein over the first 3 postnatal days. The total body protein of an infant weighing $1000 \mathrm{~g}$ is about $85 \mathrm{~g}$, and therefore assuming that the overall nitrogen (protein) loss represents true tissue catabolism then this represents a mean accumulative loss of $3 \%$ of the body's protein each day. ${ }^{4}$ Infants in the early group, on the other hand, were in positive nitrogen balance from day 1 postnatal age.

It is likely that the overall positive nitrogen balance would probably have been greater if all infants in the early study group had received amino acid without interruption in the first few days. Although it is uncertain whether there is a long term clinical advantage in this early positive nitrogen balance, it may be reasonable to assume such an advantage, particularly during the critical transitional phase of extrauterine adaptation. It must be noted, however, that although the infants in the early group were in positive nitrogen balance from day 1 , the mean daily nitrogen retention rate of both groups only reached the equivalent postconceptional age matched fetal accretion rate after day $7 . .^{48}$

In neither group were we able to achieve an energy intake greater than $209 \mathrm{~kJ} /$ day in the immediate postnatal period, which we recognise is considerably below current recommendations for enterally fed infants. In the early group, however, the overall energy intake was significantly higher than in the late group. The inability to achieve a 
critical energy threshold to maintain basal metabolism might partly explain the poor early growth seen in sick infants. The protein:energy ratio in all infants in group E, and after three days in Group L, was satisfactory. This implies that the energy supplied was adequate to permit the amino acids to be used.

We are currently studying the metabolic effects associated with the introduction of Intralipid from day 1. Intralipid has a high energy density; early introduction might permit a further increase in energy intake in these infants and improve the nitrogen sparing effect of energy.

Changes in body weight and gains in crown heel length and head circumference were similar in both groups. The mean negative changes in body weight observed in the first few days in both groups could partly be explained by shifts in body water, ${ }^{9}$ and were similar to changes reported by others. ${ }^{10}$ Enterally fed low birthweight infants show increased growth rates with protein intakes of $3.5 \mathrm{~g} / \mathrm{kg} /$ day. ${ }^{11} 12$ In our study a mean protein intake of $1.8 \mathrm{~g} / \mathrm{kg} /$ day was achieved in the first few days after the early introduction of amino acids and this is likely to have been insufficient to cause an early increase in growth. Metabolic complications precluded any further increase in protein load.

Increased phenylalanine and tyrosine concentrations were seen in some infants in both groups. Abnormalities in plasma aminograms, and in particular increased phenylalanine concentrations, are well recognised in preterm infants given Vamin as the amino acid solution ${ }^{13}{ }^{14}$; we did not see any obvious short term metabolic or other problems, but the long term implications are unknown. The introduction of the newer parenteral solutions may prevent these abnormalities. Whether breast milk or fetal lean body protein is the ideal nutritional source model for these infants, however, remains to be investigated.

A reasonable nutritional goal in feeding preterm infants is to approximate the nutritional accretion and growth seen in the fetus of comparable postconceptional age. A secondary aim in the immediate newborn period is to prevent significant catabolism and negative nitrogen balance. ${ }^{2}$ The present study shows that early introduction of an intravenous amino acid source indeed permits positive nitrogen balance in the first days of life in the sick ventilator dependent infant who cannot be fed enterally.

The authors thank the nursing and junior medical staff of the Charing Cross neonatal intensive care unit for their help in this project. Dr D Reaveley performed the amino acid analysis, Miss S Parry kindly typed the manuscript, and J Saini was funded by a Medical Research Council postdoctoral training award in human nutrition.

\section{References}

1 Heird WC, Driscoll JM Jr, Shullinger JN, Grebin B, Winters RW. Intravenous alimentation in paediatric patients. $J$ Pediatr 1972;80:351-72.

2 Adamkin DH. Nutrition in the very low birthweight infants. Clin Perinatol 1986;13:419-43.

3 American Academy of Pediatrics. Nutritional needs of low birthweight infants. Pediatrics 1985;75:976-86.

4 Shaw JCL. Parenteral nutrition in the management of sick low birthweight infants. Pediatr Clin North Am 1973;20:333-57.

5 Johnson JD, Alberitton WL, Sunshine P. Hyperammonaemia accompanying parenteral nutrition in newborn infants. J Pediatr 1972;81:154-61.

${ }^{6}$ Heird WC, Dell RB, Driscoll JM, Grebin B, Winters RW. Metabolic acidosis resulting from intravenous alimentation mixtures containing synthetic amino acids. $N$ Engl $J$ Med 1972;287:943-8.

${ }^{7}$ British Paediatric Association. Categories of babies requiring neonatal care. Arch Dis Child 1985;60:559-601.

${ }^{8}$ Kovar IZ, Saini JR, Morgan JB. The sick very low birthweight infant fed by parenteral nutrition: studies of nitrogen and energy. European Journal of Clinical Nutrition 1989;43:339-46.

9 Meurling S, Arturson G, Zaar B, Eriksson G. Energy, fat and nitrogen balance in healthy newborn infants during the first weeks after birth. Acta Chir Scand 1981;147:487-95.

10 Yu VYH, James B, Hendry P, MacMahon RA. Total parenteral nutrition in very low birthweight infants: a controlled trial. Arch Dis Child 1979;54:653-61.

" Kashyap S, Forsyth M, Zucker C, Ramakrishan R, Dell RB, Heird WC. Effects of varying protein and energy intakes on growth and metabolic response in low birthweight infants. J Pediatr 1986;100:955-63.

12 Reichman BL, Chessex P, Putet G, et al. Partition of energy metabolism and energy cost of growth in the very low birthweight infant. Pediatrics 1982;69:446-51.

13 Puntis JW, Edwards MA, Green A, Morgan I, Booth IW, Ball PA. Hyperphenylalanaemia in parenterally fed newborn babies. Lancet 1986;ii:1105-6.

14 Evans SJ, Wyne-Williams TCJE, Russell CA, Fairbrother A. Hyperphenylalanaemia in parenterally fed newborn babies. Lancet 1982;ii:1404-5.

Correspondence to Dr IZ Kovar, Charing Cross Hospital, Fulham Palace Road, London W6 8RF.

Accepted 21 March 1989 